\title{
CIBERCULTURA
}

\section{"TÃO FAMOSOS QUE VOCÊ PROVAVELMENTE NUNCA OUVIU FALAR": UMA REFLEXÃO SOBRE A “NOVA" CATEGORIA DE SUJEITOS INFLUENCIADORES DO CONSUMO}

"SO FAMOUS YOU PROBABLY NEVER HEARD OF IT":

A REFLECTION ON THE "NEW" CATEGORY OF SUBJECTS INFLUENCING CONSUMPTION

"TAN FAMOSOS QUE USTED PROBABLEMENTE NUNCA OYÓ HABLAR":

UNA REFLEXIÓN SOBRE LA “NUEVA" CATEGORIA DE SUJETOS INFLUYENTES DEL CONSUMO

Amanda Antunes ${ }^{1}$

Marcella Azevedo²

RESUMO: apesar de ser uma categoria relativamente recente, os influenciadores digitais apresentam crescimento exponencial e significativa relevância, tanto no discurso midiático, como nas práticas do marketing, disputando estes espaços com outras figuras notórias. O objetivo deste artigo é discutir as rupturas e continuidades na concepção e na prática desse fenômeno, a partir de uma análise comparativa entre as tradicionais celebridades e essa "nova" categoria de influenciadores. Para tanto, foram utilizados como recursos metodológicos a pesquisa bibliográfica e documental, além da observação das ações de marcas - entre elas, o endosso de produtos por influenciadores digitais. Como resultado, de forma sucinta, infere-se-se que as celebridades despertam no público uma admiração de caráter aspiracional, distantes que são da sua audiência.

ORCID:0000-0002-5792-8753-e-mail: amandaantunesrj@gmail.com

2 ORCID: 0000-0002-7860-3704-e-mail: msazevedo@globo.com 
Já a chave para compreensão dos influenciadores digitais é sua grande proximidade com o comum e cotidiano, se posicionando muito próximos a seus seguidores.

Palavras-chave: Influenciadores digitais. Celebridades. Consumo.

ABSTRACT: despite being a relatively recent category, digital influencers show exponential growth and significant relevance both in media discourse and marketing practices, disputing these spaces with other notorious figures. The objective of this article is to discuss the ruptures and continuities in the conception and practice of this phenomenon, from a comparative analysis between traditional celebrities and this "new" category of influencers. For this purpose, bibliographical and documentary research was used as methodological resources, besides the observation of brand actions - among them, the endorsement of products by digital influencers. As a result, it is inferred that celebrities arouses public admiration of aspirational character, far from your audience. The key to understanding digital influencers, however, is their close proximity to the common and everyday, positioning themselves very close to their followers.

Keywords: Digital influencers. Celebrities. Consumption.

RESUMEN: a pesar de ser una categoría relativamente reciente, los influencers digitales muestran un crecimiento exponencial y una relevancia significativa, tanto en el discurso de los medios como en las prácticas de marketing, disputando estos espacios con otras figuras notorias. El propósito de este artículo es discutir las rupturas y continuidades en la concepción y práctica de este fenómeno, a partir de un análisis comparativo entre las celebridades tradicionales y esta "nueva" categoría de personas influyentes. Con este fin, la investigación bibliográfica y documental se utilizó como recursos metodológicos, así como la observación de acciones de marca, entre ellas, el respaldo de productos por parte de personas influyentes digitales. Como resultado, sucintamente, parece que las celebridades despiertan en el público una admiración de carácter aspiracional, distante de su audiencia. Sin embargo, la clave para entender a los influencers digitales es su proximidad a lo común y cotidiano, posicionándose muy cerca de sus seguidores.

Palabras clave: Influenciadores digitales. Celebridades. Consumo. 


\section{Introdução}

Historicamente as estrelas da indústria do entretenimento eram as "queridinhas" do mercado publicitário. As marcas faziam grandes investimentos em suas campanhas, veiculadas em mídias de massa, investindo enormes quantias para vincular a imagem das famosas celebridades aos seus produtos e estimular o consumo. Recentemente, porém, ao lado das celebridades, muitas vezes famosas no Brasil e no mundo, há uma "nova"3 categoria de pessoas, cada vez mais procurada pelas marcas, preocupadas com uma maior eficácia no alcance e relacionamento mais estreito com seus consumidores: são os influenciadores digitais. ${ }^{4}$

O universo da moda é um bom exemplo. Nele, podemos observar significativas transformações na forma de produzir e consumir informação e conteúdos diversos dessa temática, alavancadas desde o crescente uso e popularização das remotas plataformas de blogs, por volta dos anos 2000. Proliferou-se um grande número de sites neste formato, propiciados pelas facilidades, inclusive com relação a custo - em muitos casos, custo zero - para construção e manutenção de um blog, em especial, aqueles que trazem informações diversas, opiniões, dicas e tutoriais, permeando assuntos de moda, beleza, comportamento e tendências, alcançando números astronômicos de audiência e verba publicitária. Como revela reportagem do programa Fantástico, da Rede Globo - cuja frase deu título a este artigo:

O mundo da moda está passando por uma revolução que vai muito além das passarelas. Meninas e mulheres brasileiras estão ditando o que é tendência e o que não é, tudo da telinha do celular. E elas ocupam as primeiras fileiras dos desfiles importantes, movimentam fortunas e influenciam milhões de pessoas. [...] são essas meninas tão famosas que você provavelmente nunca ouviu falar (transcrição de material audiovisual - BLOGUEIRAS, 2017).

\footnotetext{
3 O termo "nova", junto à categoria, está sendo usado aqui entre aspas para também enfatizar a ideia de que não é tudo tão novo assim, como o mercado, que se alimenta de produzir "novidades", tem apresentado. Sem dúvidas, a inserção da tecnologia digital e a internet têm contribuição significativa na proliferação e transformações possíveis ocorridas nessas práticas, o que justifica a maior atenção dada a elas contemporaneamente - inclusive com finalidade de pesquisa.

4 O termo "influenciador digital" está deixando de ser utilizado, inclusive pelo mercado, optando-se apenas por "influenciador", uma vez que não há uma separação entre os universos on-line e off-line, podendo ele atuar e ter relevância tanto nas plataformas digitais, como em ações presenciais ou, ainda, presença nas mídias tradicionais. Optamos aqui, porém, por chamar de "influenciador digital" para reforçar didaticamente que estamos nos referindo aos sujeitos cuja característica inerente é de produtor de conteúdo, sobretudo, nos ambientes digitais.
} 
Vale lembrar que a categoria da moda não éa única a constituir o universo dos blogs e outras ferramentas de redes sociais mais populares atualmente (Twitter, Facebook, Instagram, Snapchat, entre outras) com perfis que acumulam consideráveis números de audiência. Os conteúdos compartilhados enquadram-se em uma extensa variedade de temas, como tecnologia, games, estilo de vida fitness, culinária, entre tantos outros.

Em cada categoria vão se revelando perfis que se destacam e assumem o papel de influenciadores do nicho em questão. Os famosos "dos quais nunca se ouviu falar" estão sendo cada vez mais falados. Ainda que muito provavelmente não sejam conhecidos do grande público, são inegáveis sua presença, força e influência, sobretudo entre os jovens, considerando tanto quem produz, como quem consome esses conteúdos. Para além do poder de sedução junto a esse público específico, os influenciadores digitais despertam a atenção e são alvo de investimentos das mais diversas marcas, interessadas justamente nessa aproximação diferenciada com os jovens consumidores.

Números recentes apontam que há atualmente seis milhões de influenciadores digitais no mundo, sendo que 313 mil deles são brasileiros. Estima-se que no país há, pelo menos, 84 empresas, entre agências, redes e plataformas, que atuam na promoção e gerenciamento de relacionamento entre marcas e influenciadores digitais (QUINALIA, 2017).

Um grande influenciador digital no Brasil ganha entre 50 mil e 150 mil reais por campanha no YouTube. Canais com menos seguidores chegam a conseguir entre um mil e cinco mil reais pelo mesmo trabalho (CALDAS, 2017). A Celebryts, plataforma on-line que dá suporte às empresas na busca por influenciadores digitais junto a seu público consumidor, foi lançada há pouco mais de dois anos (a versão beta foi ao ar em dezembro de 2016) e já conta com mais de 50 mil influenciadores digitais brasileiros cadastrados e mais de 2000 empresas clientes e agências (CELEBRYTS, 2018). Dados como esses apontam o crescimento e ganho de importância dos influenciadores digitais, agentes cada vez mais relevantes no marketing de influência.

Sem dúvidas, a celebridade exerce influência sobre o público que consome sua imagem mas, não somente por isso, ela se enquadra no que vem se chamando de influenciadores digitais. Tampouco estes, por sua relevância e certa "fama" no universo digital, com alcance amplo ou restrito, podem ser conceitualmente caracterizados como celebridades. Fama e potencial de influência não são os únicos balizadores de tais fenômenos. Conforme já afirmou Alex Primo (2009b, p. 3), "não há nada errado em utilizar tal termo [celebridade] livre e informalmente, até mesmo como metáfora. Contudo, quando exige-se rigor na reflexão, como é o caso da discussão acadêmica, urge delimitar-se bem o conjunto conceitual". 
Sendo assim, o objetivo deste artigo é discutir as rupturas e continuidades na concepção e na prática desse fenômeno midiático que são os influenciadores digitais. Percebidos como "nova" categoria de sujeitos, eles vêm ganhando significativa relevância, tanto no discurso midiático, como nas práticas do marketing, disputando estes espaços com outras figuras notórias, como as tradicionais celebridades.

Analisar as dinâmicas que caracterizam a atuação dos influenciadores digitais, assim como as relações simbólicas envolvidas em sua interação com o público pode se apresentar profícuo para entender a procura cada vez maior das marcas por se atrelarem a esses agentes, na busca por um processo de endosso de produtos e humanização da marca, além de vínculos mais fortes com seus consumidores. Como pano de fundo, revelam-se questões de visibilidade, autenticidade e influência, em um contexto social transformado pela intensa presença da tecnologia nas práticas comunicacionais contemporâneas.

\section{A valorização do sujeito comum}

De acordo com Boorstin (2006), é possível estabelecer uma relação direta entre os que eram considerados heróis há alguns séculos e o que são as celebridades contemporâneas: "Dois séculos atrás quando um grande homem aparecia as pessoas procuravam pelo propósito de Deus nele; hoje nós procuramos por seu agente de imprensa" (BOORSTIN, 2006, p. 72)5 Os grandes heróis de nossa história ficaram conhecidos por seus grandes feitos e, assim, eram vistos como detentores de um propósito divino, quase semideuses, completamente apartados das pessoas comuns. Já as celebridades são conhecidas por estarem presentes nas mídias: "O herói era um grande homem; a celebridade é um grande nome" (BOORSTIN, 2006, p. 81). ${ }^{6}$

Edgar Morin (1989) estudou o fenômeno das grandes estrelas de cinema e aponta que elas eram vistas como divindades pelo público: “Quando se fala em mito da estrela, trata-se portanto em primeiro lugar do processo de divinização a que é submetido o ator de cinema, e que faz dele ídolo das multidões" (MORIN, 1989, p. 26). Apesar da ausência da realização de grandes feitos enquanto sujeitos, Morin aponta que atores ou atrizes absorviam traços heroicos de seus personagens. Ao mesmo tempo, esses artistas emprestavam muito de si para eles, numa relação que tornava difícil para o público perceber o que era ou não uma característica genuína de cada um.

\footnotetext{
5 No original: "Two centuries ago when a great man appeared, people looked for God's purpose in him; today we look for his press agent".

6 No original: "The hero was a big man; the celebrity is a big name".
} 
No início, aos olhos do público, as estrelas de cinema viviam quase no Olimpo. Suas casas luxuosas, suas vidas glamorosas e seus romances arrebatadores mostram que "Vivem muito longe, muito acima dos mortais. Consomem as suas vidas no capricho e no jogo" (MORIN, 1989, p. 9). A partir de 1930, porém, há um movimento de valorização da vida íntima e privada desses artistas, aproximando-os do cotidiano das pessoas comuns.

É dessa forma que a evolução que degrada a divindade da estrela estimula e multiplica os pontos de contato entre estrelas e mortais. Longe de eliminar o culto, incentiva-o. Mais presente, mais familiar, a estrela está quase à disposição de seus admiradores: daí o florescimento dos fãs-clubes, revistas, fotografias, correspondência, que institucionalizam o fervor. Toda uma rede de canais conduz a partir daí a homenagem coletiva, que retorna aos fiéis na forma dos mil fetiches que eles reclamam (MORIN, 1989, p. 20).

Para Morin, essa aproximação com o público atende a desejos mais profundos das massas e reconfigura as relações entre real e imaginário, agora também mais próximas. A indústria cinematográfica e do entretenimento vão se apropriar da vida privada do artista, transformando-a, também, em mercadoria:

A vida privada-pública das estrelas tem sempre eficácia comercial, ou
seja, publicitária. Além disso, a estrela não é apenas sujeito, mas também
objeto da publicidade: ela apresenta perfumes, sabonetes, cigarros
etc., multiplicando assim sua utilidade comercial (MORIN, 1989, p. 75).

Ao analisar a cultura das celebridades contemporâneas, Rojek (2008) argumenta que os meios de comunicação de massa permitem uma aproximação ainda maior entre público e celebridades. A mídia é ubíqua e torna a imagem da celebridade nela presente também amplamente disseminada. Porém, essa relação massiva é, por outro lado, superficial e indireta, uma vez que sempre mediada pelas representações. Tem-se aí o que autor denomina de "interação parassocial", termo "usado para se referir a relações de intimidade construídas através da mídia, e não pela experiência direta e encontros cara a cara" (ROJEK, 2008, p. 58). O público, então, passa a ter amplo acesso à vida privada das celebridades, mas esse acesso é sempre de "segunda categoria", uma vez que amplamente mediado.

Como vimos, então, os heróis eram pessoas que ficaram conhecidas por seus grandes feitos e vistos como divindades, uma vez que portadores de um propó- 
sito especial de Deus. Já as estrelas eram consideradas semideusas que, em uma relação dialética com seus personagens, herdavam deles os atos de heroísmo. As celebridades contemporâneas, por sua vez, se tornam famosas por estarem na mídia de massa, como afirma Boorstin: "A celebridade é uma pessoa que é conhecida por ser muito conhecida" (BOORSTIN, 2006, p. 79).?

Essas transformações mostram uma aproximação cada vez maior com o público, que busca identificar elementos de seu próprio dia a dia na vida cotidiana das celebridades. Não por acaso, portanto, é notória a valorização, cada vez mais crescente, do ordinário, do real, do cotidiano e do sujeito comum pelas produções midiáticas. Por outro lado, os sujeitos, eles mesmos, procuram representações de si as mais variadas, espetacularizando o comum, ao dar visibilidade a aspectos corriqueiros de suas vidas.

Vera Follain de Figueiredo (2010) aponta que

\begin{abstract}
O interesse pelas chamadas histórias "verdadeiras" de pessoas não famosas, [...] ao lado do sucesso dos reality shows na televisão e da voga dos filmes documentais, dentre outros fenômenos marcantes nas produções artísticas e midiáticas do final do século $X X$ e do início do XXI, enquadra-se na tendência para a busca do "real como matéria bruta", acompanhada da rejeição do ficcional, que nos permite falar em um movimento de retorno a uma estética realista [...] (FIGUEIREDO, 2010, p. 69-70).
\end{abstract}

Neste sentido, podemos observar a proliferação de tais programas, os reality shows, que mostram o dia a dia de pessoas convivendo em uma casa, desempenhando ações tão banais como escovar os dentes ou tomar banho. Há os programas que confinam pessoas já famosas e há aqueles que o fazem com pessoas comuns, mas que, paradoxalmente, serão famosas ao fim do programa, uma vez que tiveram suas vidas comuns veiculadas em mídias de massa.

Podemos observar também blogs, canais no YouTube e perfis em outros sites de redes sociais que se popularizam justamente como vitrine para exposição da "vida como ela é". Na medida em que crescem as possibilidades de uso da internet, somadas à proliferação dos sites de redes sociais, aumenta a participação de todo tipo de sujeito, inclusive os comuns, nessas arenas, estes últimos extrapolando a audiência e atuando também na produção de conteúdo.

No original: "The celebrity is a person who is known for his well-knownness". 
Assim, ao mesmo tempo em que celebridades se aproximam do público, ao compartilharem momentos cotidianos de suas vidas, também as pessoas comuns obtêm visibilidade ao se exibirem nas plataformas digitais. Pode-se dizer que, ao postar a imagem de uma tarefa ordinária, o usuário, tal qual a celebridade, está desempenhando uma prática de exibição de sua vida cotidiana. Esse sujeito comum assume, portanto, práticas de "micro-celebridade" (SENFT, 2008; MARWICK \& BOYD, 2010), através de um discurso carregado de proximidade e autenticidade. Em paralelo, aqueles que assistem - incluindo os próprios que se exibem, uma vez que ora assumem um papel, ora se encontram no lado oposto -, já habituados com os conteúdos produzidos pela mídia nos mais variados produtos, tendo a revista de fofocas como o maior referente, seguem consumindo "cotidianos alheios" oriundos, agora, das mais variadas fontes.

Essa espécie de processo pedagógico advindo do universo das celebridades, sustentado e amplamente projetado pelos meios de comunicação de massa, que impulsiona pessoas comuns a reproduzirem certas práticas (de exibir e explorar imagens do cotidiano), também ensinou a desprezar esse mesmo meio ou, pelo menos, as figuras que nele circulam - embora não inteiramente, uma vez que sabemos a força que ainda possuem as celebridades midiáticas. A crescente exploração de situações mundanas e corriqueiras de celebridades dadas ao consumo das pessoas comuns fez crescer o irreverente anseio pelo ordinário real. Assim, cresce também o número de sujeitos comuns que passam a disputar espaço nos tronos da admiração e referencialidade anteriormente ocupados tão somente pelas celebridades - além de outras pessoas famosas e figuras públicas - com o respaldo do controlado e fechado sistema dos grandes conglomerados de mídia.

É neste cenário que surgem os influenciadores digitais, que se aproximam ainda mais do público do que as celebridades com presença midiática. Eles mostram seu dia a dia e fatos de sua vida ordinária, compartilhando ainda com o público geral a inexistência de uma "famosidade", ao menos não de amplo alcance. Tem-se aí, então, a possibilidade de identificação ainda maior e, mais, a configuração de uma relação que se dá de maneira mais direta. Eles se comunicam com o público sem o intermédio dos tradicionais produtores de comunicação. Possuem seus próprios canais e geram conteúdo autoral (se distanciando da "interação parassocial" de que nos falara Rojek e que mencionamos mais acima), estabelecendo os caminhos para interações mais autênticas e duradouras, em que ambas as partes desfrutam de certa equiparação, sem o endeusamento de nenhuma delas.

A cultura do mainstream não é válida para definir esse sujeito influenciador, tampouco suficiente para determinar seu potencial de influência. $O$ impacto de um in- 
fluenciador digital se faz relevante pelo papel que exerce naquele espaço de complexas relações e interações sociais construído sob condições de proximidade, familiaridade e, até mesmo, empatia e afeto da parte de seus seguidores. Uma maior proximidade e empatia forjam também um aspecto (espera-se) mais real, de uma pessoa concreta, imersa em uma vida real. A intensa produção de imagens e histórias ficcionalizadas que sempre estiveram presentes nos mais variados produtos midiáticos, sobretudo na publicidade, parece revelar uma pista para entender o anseio por experiências e narrativas mais autênticas que vigoram na atualidade, além de se configurar como o grande desafio para os publicitários em suas estratégias de estabelecimento de relacionamento e propagação das mensagens da marca junto a seu público.

Nas ações de relacionamento com influenciadores digitais, a marca aparece hermeticamente incorporada no contexto de uma vida de um consumidor - ou potencial consumidor - que se torna uma nova fonte de modelo de atuação humana. As mensagens publicitárias, dessa maneira, são travestidas com o discurso do outro, ou seja, a emissão da mensagem se dá, paradoxalmente, pelo discurso do seu próprio receptor/consumidor. Assim, a publicidade se insere no contexto contemporâneo de desejo por realidades mais acessíveis, próximas e, por conseguinte, críveis, contudo, ao mesmo tempo, corrobora com a proliferação de produções midiáticas que trazem como principal apelo sujeitos comuns, situações cotidianas e vidas reais.

Tais sujeitos são considerados influenciadores porque "as pessoas levam em consideração a opinião deles e se abastecem da opinião deles para ajudar a formar a sua opinião normalmente utilizando as redes sociais" (LAURA KROEFF - transcrição de material audiovisual - BLOGUEIRAS, 2017), principalmente dentro da temática de atuação do influenciador digital (moda e tendência, saúde e beleza, culinária, tecnologia, jogos, literatura, política, etc). Conforme ressalta Bia Granja, "o que faz com que esses influenciadores sejam, de fato, grandes influenciadores é que eles fazem esse conteúdo do ponto de vista muito pessoal e, por isso, muito autêntico" (transcrição de material audiovisual - Cuidados, 2016).

Podemos dizer, então, que o influenciador digital representa um modo mais autêntico de testemunho sobre produtos, emprestando a esta marca à qual se vincula os sentidos simbólicos inerentes a seu próprio modo de ser e estilo de vida. Isso se dá através de suas ações e exposições nos canais de interação com sua rede de contatos, transferindo tal autenticidade para a marca, ao mesmo tempo em que se apropria do potencial distintivo que tal afiliação lhe proporciona, mas também dos valores inerentes a esta mesma marca, em grande medida, pertinentes com seu perfil. 


\section{Celebridades e influenciadores digitais: rupturas e continuidades}

Celebridades e influenciadores digitais são categorias que não necessariamente se excluem, pelo contrário, há muitos pontos de contato e convergências entre elas. No que tange ao potencial de alcance do público e à popularidade de uma forma geral, tem-se que a celebridade, sem dúvida, possui uma presença mais constante na mídia de massa, porém, as "curtidas", comentários e compartilhamentos nas redes sociais no ambiente da internet, tantas vezes demonstram resultados impressionantes de engajamento. $O$ alcance da mensagem certamente é menor, porém trata-se de uma audiência qualificada e engajada, o que se reflete em uma comunicação bastante efetiva. Influência, portanto, não está necessariamente associada a grandes números de audiência, como atesta Felipe lacocca, CEO da agência de marketing de influência IWN, em entrevista para o site Revista PEGN:

\footnotetext{
O mercado publicitário tende a relacionar influência a números de audiência. Trata-se de uma visão bastante míope. A audiência é apenas um dos pontos a ser considerado. A capacidade de engajar seguidores está ligada à veracidade da narrativa e à representatividade do produtor de conteúdo entre determinado público. É a transmissão de uma mensagem autoral e humanizada que torna essas pessoas atraentes para os consumidores (GOMES, 2016).
}

Há que se destacar também o possível trânsito desses sujeitos - célebre e influenciador digital - entre ambas as categorias. Muitas vezes a celebridade, por conta de sua massiva presença midiática e o consequente alcance da fama, mobiliza um enorme número de seguidores nas redes sociais virtuais e, assim, também é tratada como influenciadora digital. Em paralelo, personalidade genuinamente das redes sociais youtubers, instagrammers e afins - podem despertar o interesse e, consequentemente, certa visibilidade nos veículos de comunicação de massa, tornando-se celebridades.

Existe ainda aqueles que não alcançam uma repercussão consolidada pela grande mídia, o que não permite considerá-los (ainda) celebridades, mas carregam consigo os traços da emblematização da figura célebre, sendo considerados verdadeiras celebridades do ambiente digital por movimentar legiões de fãs, em alguns casos multidões deles. É interessante observar nesse fenômeno que os "novos famosos" não se limitam às fronteiras da chancela das mídias de amplo alcance dirigidas pelos potentes produtores midiáticos. 
Essa "entrada" dos influenciadores digitais nas mídias mainstream, porém, não se dá por acaso e reflete a lógica midiática e mercadológica que delineia também essa categoria. Cada vez mais a atuação como influenciador digital deixa de ser uma atividade paralela, caminhando a passos largos para a profissionalização. Criadores de conteúdo, que buscam ser remunerados por essa atividade e viver da renda advinda daí, empenham-se em buscar números significativos de seguidores e certo grau de "fama", que vão legitimar o seu potencial de influenciar pessoas, o que por sua vez vai dar a ele maior popularidade e notoriedade, num ciclo que se retroalimenta. Em certo momento desse processo, outros elementos determinantes se inserem: as marcas interessadas em estabelecer parcerias e/ou, como dito anteriormente, grandes veículos consagrando e atribuindo ainda mais visibilidade a esse sujeito.

Um dos elementos mais básicos e fundamentais que caracteriza uma celebridade, conforme apontam alguns autores (ROJEK, 2008; MARSHALL, 1997; BOORSTIN, 2006; PRIMO, 2009a, 2010), é o suporte do sistema midiático e a intrínseca relação com a indústria da cultura de massa. Nas palavras de Rojek, "a representação da mídia de massa é o princípio-chave na formação da cultura da celebridade" (ROJEK, 2008, p. 15). É nesse universo que a fama se dissemina, amplifica e estabelece, mas também onde se finda, dada a ausência da celebridade nesse espaço de visibilidade.

Já o influenciador digital se constitui sob uma lógica bastante intrigante. A notoriedade que lhe é pertinente independe do envolvimento com marcas ou da chancela da mídia. Seus seguidores legitimam sua "fama localizada" (ROJEK, 2008), mas isso não se revela suficiente para alcançar patamares mais altos de sucesso e ganhos financeiros. Conquistar os olhares de "investidores”, portanto, é fundamental para consolidar o próprio status como influenciador digital e a entrada no hall das personalidades interessantes, sobretudo quando é uma grande marca ou grande veículo, trazendo mais marcas, projetos e/ou convites de participações em produções diversas.

Vale destacar que conquistar esse lugar não é tarefa fácil. Anna Clara Serpa, por exemplo, conta, na reportagem do Fantástico supracitada, que trabalha fazendo a divulgação de algumas marcas no seu perfil do Instagram, apresentando seu lifestyle, falando de moda, viagens, gastronomia etc., atividade pela qual é remunerada. A influenciadora digital passou a se dedicar a essa atividade como profissão de forma exclusiva e, em um ano, alcançou 11.000 seguidores, tendo investido até então cerca de $\mathbf{2 5 . 0 0 0}$ reais com fotógrafo, maquiador, consultoria de estilo e de marketing para produção do conteúdo nos sites de redes sociais. No entanto, até o momento da exibição da reportagem, ainda não tinha conseguido, como disse, recuperar o retorno do investimento inicial realizado, nem alcançar a posição e a remuneração desejadas. 
Tem se tornado cada vez mais comum a procura de influenciadores digitais por empresas que oferecem o serviço de self-branding com foco na projeção de imagem, além do gerenciamento das atividades, incluindo a mediação em contratos diversos, sobretudo, publicitários. Tais empresas e profissionais se aproximam bastante dos "intermediários culturais", que menciona Rojek, cuja grande função é auxiliar uma celebridade a adquirir reconhecimento público. Como diz o autor, seriam uma espécie de "diretores de cena da sua presença aos olhos do público" (ROJEK, 2008, p.12), em outras palavras, são profissionais que contribuem significativamente na administração dessa imagem-marca. Tal processo de projeção na web pode prover meios, por vezes, fins, distintos daqueles de construção de uma celebridade midiática tradicional, mas, sem dúvida, possui bases bastante similares com foco no atrair de audiência, negócios e benefícios possíveis a partir do valor dessa imagem que se concretiza no reconhecimento do público que segue, assiste e/ou interage com o influenciador digital.

É preciso ressaltar que, para a celebridade tradicional, a presença constante na mídia não é o único parâmetro de sucesso, há que se destacar também a importância do público receptor que vai legitimar o reconhecimento desse sujeito como figura célebre. O fascínio por quem a celebridade é e/ou pelo que ela faz, ou simplesmente o encanto por sua presença sustentada nas mídias, leva a uma idealização dessa figura - cujo rosto torna-se tão familiar - e a faz detentora de um poderoso potencial de sedução e magia. É justamente esse potencial que desperta o interesse, além do público, das marcas.

Já o universo das redes sociais digitais possui uma lógica diferente, que consiste em uma inerente sensação de proximidade, possibilitada por interações mais diretas e a consequente construção de relacionamentos mais próximos. Entretanto, intrigantemente, o fascínio pelo mundo particular do outro, exposto no conteúdo produzido a partir de sua experiência cotidiana, e a curiosidade pela pessoa que se apresenta e seu dia a dia também acontecem entre seguidores e influenciador digital, podendo ser percebido o efeito dessa, digamos, similar magia nas reações exacerbadas quando o influenciador digital é encontrado em um ambiente fora das telas das redes sociais on-line.

A fama e o reconhecimento, portanto, dependem - além dos interesses e ações do mercado midiático para celebridades tradicionais, ou dos esforços empreendidos de influenciadores digitais - também do público receptor para existir, independente de que seja esse público de massa ou de nicho. Isso se dá de maneira ainda mais evidente em grupos sociais específicos, que englobam aqueles que convivem no mesmo sistema social e compartilham valores, hábitos, práticas e preferências. 
Desta forma, tem-se que a fama não pode ser considerada binária - na contraposição de sua presença ou ausência -, ter como grande balizador somente o alcance numérico de conhecimento ou reconhecimento, ou ainda baseada apenas na presença midiática. É preciso considera-la dentro de nichos, percebendo a relevância do sujeito que se destaca dentro de seu universo específico, a saber, onde ele se construiu simbolicamente.

Somando-se às discussões empreendidas até aqui, é válido mencionar ainda a perspectiva de Marwick e Boyd (2011) sobre o conceito de celebridade, que se contrapõe à visão que o entende a partir de características intrínsecas, rótulos externos ou uma qualidade individual vinculada à fama, deslocando a ideia de celebridade ligada à figura célebre para o entendimento de celebridade enquanto um conjunto de práticas que "envolve a manutenção contínua de uma base de fãs, intimidade performática, autenticidade e acesso, e a construção de uma pessoa consumível" (MARWICK \& BOYD, 2011, p. 140) ${ }^{8}$, observado sobretudo no ambiente das mídias digitais. Marwick (2010) argumenta que uma série de fatores permite propor a transformação do conceito, entre eles: a expansão do fenômeno, já que o espetáculo e a encenação extrapolam o entretenimento alcançando outras esferas como a política, os negócios, etc; a fragmentação da cultura de massa que possibilitou o estabelecimento de uma cultura de nicho, quebrando a lógica exclusiva do mainstream; o amplo conhecimento da engrenagem do processo de celebrificação, tais como gestão e produção de imagem, comumente difundidos nos diversos produtos midiáticos; além da proliferação de canais e perfis nas mídias sociais de pessoas famosas, ou não, que compartilham ostensivamente conteúdo e alcançam grande público.

Para Marwick e Boyd (2011), as práticas que se propagaram nos sites de redes sociais por aqueles que adquiriram notoriedade na rede - o que convencionou-se chamar de micro-celebridade (SENFT, 2008) - são apropriadas também pelas "celebridades tradicionais" nesse espaço social, visando o gerenciamento da autoimagem e da popularidade.

Configura-se aqui um dos principais pontos de aproximação entre celebridade e influenciador digital. Embora este último não possa ser considerado celebridade, por rupturas diversas já articuladas anteriormente, é possível dizer que se assemelha enquanto prática, principalmente nas ferramentas de redes sociais digitais, partindo da perspectiva de Marwick e Boyd (2011). Ou, pode-

\footnotetext{
8 No original: "involves ongoing maintenance of a fan base, performed intimacy, authenticity and access, and
} construction of a consumable persona". 
mos dizer que carrega traços de celebridades (tradicionais), na medida em que uma série de continuidades podem ser observadas nessa nova categoria que reúne algumas qualidades e aspectos da figura célebre, além de mecanismos constituintes bastante similares, tendo, no entanto, como elemento intrínseco primordial o aspecto ordinário de uma vida real e uma forma de comunicação autêntica - ainda que, por vezes, orientada por estrategistas, já que tal orientação é, em geral, exatamente esta: "É muito importante que a blogueira ou a influenciadora digital viva a vida dela de verdade" (Alice Ferraz - transcrição de material audiovisual - Blogueiras, 2017).

Longe de engessar as discussões aqui elaboradas, tampouco a tipificação proposta, mas de modo a esquematizar as observações do fenômeno, propomos o quadro abaixo, que permite uma rápida visualização da síntese de nossa reflexão sobre as relações entre celebridades e influenciadores digitais:

Quadro 1 - Celebridades versus influenciadores digitais: dados comparativos sintetizados

\begin{tabular}{|c|c|}
\hline Celebridades & Influenciadores digitais \\
\hline Investimento em mídia alto e concentrado & Investimento menor e mais pulverizado \\
\hline Maior alcance & Maior engajamento \\
\hline Mídia de massa & Nichos de público \\
\hline $\begin{array}{c}\text { Depoimento sobre ou apresentação de um produto } \\
\text { ou marca }\end{array}$ & $\begin{array}{c}\text { Depoimento/ Apresentação de um produto + } \\
\text { produção de conteúdo + mídia própria (caráter de } \\
\text { verdade e de autenticidade) }\end{array}$ \\
\hline $\begin{array}{c}\text { Campanhas em várias etapas - maior tempo de } \\
\text { produção }\end{array}$ & $\begin{array}{c}\text { Processo de produção concentrado - maior agilidade } \\
\text { Mais distante do público }\end{array}$ \\
\hline $\begin{array}{c}\text { Ambos têm carisma, reconhecimento, poder de } \\
\text { influência e estão atrelados a valores positivos que } \\
\text { interessam às marcas }\end{array}$ & \begin{tabular}{c} 
Maior proximidade com o público \\
\hline
\end{tabular} \\
\hline
\end{tabular}

Fonte: elaborado pelas autoras. 


\section{Considerações finais}

A proposta de analisar rupturas e continuidades entre essa ainda "nova" categoria dos influenciadores digitais e as já tradicionais celebridades, passa ao largo da simples oposição entre elas, ou mesmo da tentativa contrária, de "encaixar" os influenciadores digitais no rótulo das celebridades. O interesse, de fato, foi tentar entender aspectos e características intrínsecos a cada uma delas, assim como pontos de contato entre ambas, de modo a compreender o grande poder de sedução dos influenciadores digitais junto ao público e, mais ainda, perante as marcas, que estão cada vez mais migrando seus investimentos de comunicação dos grandes veículos da mídia de massa para canais e páginas de influenciadores que abrangem um público na internet bem mais restrito, porém de maneira mais engajada e duradoura.

Celebridades e influenciadores digitais, grosso modo, são indivíduos que se destacam diante do público em geral, formado por sujeitos comuns. Apresentam, portanto, um caráter de excepcionalidade, são peças de um sistema que explora tanto sua imagem quanto sua identidade. Possuem notoriedade, seja ela por meio da presença na mídia de massa ou a partir de uma audiência mais concentrada que, de qualquer forma, assegura certo poder de influência. Normalmente compartilham atributos positivos, que despertam a admiração do público e o interesse das marcas por se associarem a eles.

As celebridades midiáticas tradicionais costumam mobilizar grandes e concentrados investimentos de mídia de massa, de amplo alcance. Sua imagem é construída com base em sua personalidade midiática, despertando no público uma identificação de nível aspiracional. As campanhas de marketing das quais participam costumam ser permeadas por várias etapas de produção, cada um a cargo de um especialista diferente, o que leva a um maior tempo necessário para ir ao ar. Ela participa dando um depoimento sobre determinado produto ou marca, a partir de um script pré-determinado e de uma encenação que tem lugar em frente às câmeras. Se encontra em um lugar distante do público, como se ocupasse um pedestal imaginário, sendo alvo de grande admiração, que por vezes pode chegar à idolatria.

Já os influenciadores digitais atuam a partir de parâmetros diferentes. Individualmente, a maior parte deles recebe investimentos relativamente menores, uma vez que pulverizados entre diversos influenciadores. De modo geral, não se dirigem a um público amplo e massivo, mas a nichos específicos e coesos. Sua audiência é, sem dúvida, menor, porém seu poder de comunicação com ela é grande e com alto potencial de engajamento. Ao falar sobre determinada marca ou produto, o faz a partir de um depoimento tido como mais autêntico, que 
soa mais verdadeiro, porque, como se espera, é ele o principal responsável pela criação da mensagem, com sua linguagem e jeito próprio de ser. O influenciador digital concentra em si mesmo as diversas etapas da produção de uma campanha, é o criador do conteúdo que, por sua vez, será veiculado em canal próprio, o que ajuda a lhe conferir um caráter de verdade e de autenticidade e, também, assegura uma agilidade muito maior para uma campanha ir ao ar. Sua imagem perante o público é construída a partir de uma pessoa real, bastante próxima das pessoas comuns, despertando em sua audiência uma identificação de nível inspiracional.

A chave, portanto, que nos dá caminhos para uma maior compreensão do crescimento e ganho de importância dos influenciadores digitais parece ser sua grande proximidade com o comum, o ordinário, o cotidiano. Isso desperta a admiração do público, que o olha não em um pedestal, mas em um lugar, sem dúvida também cobiçado, mas onde se entende ser bastante possível a qualquer um chegar. Longe de despertar uma admiração pelo excepcional, o faz pelo autêntico, verdadeiro e real, mais próximo e acessível, ele é inspiração, que mostra que pode estar logo ali, a tão desejada realização.

\section{REFERÊNCIAS}

BLOGUEIRAS, ou influenciadoras digitais, ganham fama e dinheiro. Fantástico - Rede Globo, edição do dia 26 fev. 2017. Disponível em http://g1.globo.com/fantastico/noticia/2017/02/blogueiras-ou-influenciadoras-digitais-ganham-fama-e-dinheiro.html. Acesso em: 9 mar. 2017. https://doi.org/10.22478/ufpb.1807-8931.2017v13n9.36149

BOORSTIN, Daniel Joseph. From hero to celebrity: the human pseudo-event. In: MARSHALL, P. D (ed.). The celebrity culture reader. New York: Routledge, 2006. p. 72-90.

CALDAS, Edson. Revista revela quanto ganham os maiores influenciadores digitais do mundo. Época Negócios, on-line, 26 abr. 2017. Disponível em: http://epocanegocios. globo.com/colunas/Tecneira/noticia/2017/04/revista-revela-quanto-ganham-os-maiores-influenciadores-digitais-do-mundo.html. Acesso em: 14 nov. 2018. https:// doi.org/10.11606/d.27.2019.tde-22022019-144714

CELEBRYTIS, 2018. Site institucional. Disponível em: https://celebryts.com/. Acesso em: 14 nov. 2018.

OS CUIDADOS ao contratar um influenciador. Meio e Mensagem, on-line, ago. 2016. Seção vídeos. Disponível em: http://www.meioemensagem.com.br/home/videos/2016/08/11/os-cuidados-ao-contratar-um-influenciador.html. Acesso em: 14 nov. 2018.

FIGUEIREDO, Vera Lúcia Follain de. Narrativas migrantes: literatura, roteiro e cinema. Rio de Janeiro: Ed. PUCRio: 7Letras, 2010. 
GOMES, Thomaz. Como ser um influenciador de sucesso nas redes sociais. Pequenas Empresas e Grandes Negócios, on-line, 13 set. 2016. Disponível em: http://revistapegn. globo.com/Startups/noticia/2016/og/como-fazer-sucesso-como-influenciador-nas-redes-sociais.html. Acesso em: 14 de nov. 2018. https://doi.org/10.31219/osf.io/mf7t6

MARSHALL, P. David. Celebrity and power: fame in contemporary culture. London: University of Minnesota Press, 2004.

MARWICK, Alice. Update: Celebrity, Publicity, and Self-Branding in Web 2.o. New York, 2010. 497 f. Tese (Doutorado em Filosofia) - New York University.

MARWICK, Alice; BOYD, Danna. To see and to be seen: celebrity practice on twitter. Convergence: The International Journal of Research into New Media Technologies, v. 17, ed. 2, p. 139-158, 2011. https://doi.org/10.1177/1354856510394539

MORIN, Edgar. As estrelas: mito e sedução no cinema. Rio de Janeiro: J. Olympio, 1989.

PRIMO, Alex. De narcisismo, celebridades, celetoides e subcelebridades: o caso Tessália e sua personagem Twittess. Comunicação, mídia e consumo, São Paulo, v. 7, n. 20, p. 159-189, nov. 2010.

PRIMO, Alex. A busca por fama na web: reputação e narcisismo na grande mídia, em blogs e no Twitter. XXXII CONGRESSO BRASILEIRO DE CIÊNCIAS DA COMUNICAÇÃO, 2009a, Curitiba. Anais [...] [recurso eletrônico] São Paulo: Intercom, 2009a. Disponível em: <http://www.ufrgs.br/limc/PDFs/fama.pdf> Acesso em: 14 nov. 2018. https://doi. org/10.1590/s1809-58442013000200005

PRIMO, Alex. Existem celebridades da e na blogosfera? Reputação e renome em blogs. XVIII ENCONTRO DA COMPÓS - ASSOCIAÇÃO NACIONAL DOS PROGRAMAS DE PÓS-GRADUAÇÃO EM COMUNICAÇÃO, 2009, Rio de Janeiro. Anais [...] [recurso eletrônico], Rio de Janeiro: Compós, 2009b. Disponível em: <http:// www.compos. org.br/data/biblioteca_1484.pdf> Acesso em: 12 set. 2019. https://doi.org/10.22409/ poiesis.2033.217-236

QUINALIA, Eliane. Carreiras estão surgindo por conta dos influenciadores digitais. Exame, on-line, 11 ago. 2017. Disponível em: http://exame.abril.com.br/carreira/conheca-as-carreiras-que-surgiram-por-conta-dos-influenciadores/. Acesso em: 14 nov. 2018.

ROJEK, Chris. Celebridade. Rio de Janeiro: Rocco, 2008.

SENFT, Theresa M. Camgirls: celebrity and community in the age of social networks. New York: Peter Lang, 2008. 


\section{Dados da autora:}

Amanda Antunes - e-mail: amandaantunesrj@gmail.com

Doutora e mestre pelo Programa de Pós-Graduação em Comunicação da PUCRio. Professora da Universidade Católica de Petrópolis (UCP) e da Escola de Comunicação e Design Digital (ECDD) Infnet.

\section{Endereço da autora:}

Escola de Comunicação e Design Digital, Universidade Católica de Petrópolis Rua Benjamin Constant, 213, Centro - Petrópolis (RJ) - Brasil

\section{Dados da autora:}

Marcella Azevedo - e-mail: msazevedo@globo.com

Doutoranda e Mestre pelo Programa de Pós-Graduação em Comunicação da PUC-Rio.

\section{Endereço da autora:}

Departamento de Comunicação Social, Pontifícia Universidade Católica do Rio de Janeiro - Rua Marquês de São Vicente, 225 - Prédio Kennedy - $6^{\circ}$ andar, Gávea - Rio de Janeiro (RJ), Brasil 